\title{
Review \\ GnRH-Related Neurohormones in the Fruit Fly Drosophila melanogaster
}

\section{David Ben-Menahem}

Citation: Ben-Menahem, D. GnRH-Related Neurohormones in the Fruit Fly Drosophila melanogaster. Int. J. Mol. Sci. 2021, 22, 5035. https:// doi.org/10.3390/ijms22095035

Academic Editor: Andrew G. Ewing

Received: 12 April 2021

Accepted: 6 May 2021

Published: 10 May 2021

Publisher's Note: MDPI stays neutral with regard to jurisdictional claims in published maps and institutional affiliations.

Copyright: (C) 2021 by the author. Licensee MDPI, Basel, Switzerland. This article is an open access article distributed under the terms and conditions of the Creative Commons Attribution (CC BY) license (https:// creativecommons.org/licenses/by/ $4.0 /)$.
Department of Clinical Biochemistry and Pharmacology, Faculty of Health Sciences, Ben-Gurion University of the Negev, Beer-Sheva 8410501, Israel; dbm@bgu.ac.il; Tel.: +972-8-6477485; Fax: +972-8-6479303

\begin{abstract}
Genomic and phylogenetic analyses of various invertebrate phyla revealed the existence of genes that are evolutionarily related to the vertebrate's decapeptide gonadotropin-releasing hormone $(\mathrm{GnRH})$ and the $\mathrm{GnRH}$ receptor genes. Upon the characterization of these gene products, encoding peptides and putative receptors, GnRH-related peptides and their G-protein coupled receptors have been identified. These include the adipokinetic hormone (AKH) and corazonin (CRZ) in insects and their cognate receptors that pair to form bioactive signaling systems, which network with additional neurotransmitters/hormones (e.g., octopamine and ecdysone). Multiple studies in the past 30 years have identified many aspects of the biology of these peptides that are similar in size to GnRH and function as neurohormones. This review briefly describes the main activities of these two neurohormones and their receptors in the fruit fly Drosophila melanogaster. The similarities and differences between Drosophila AKH/CRZ and mammalian GnRH signaling systems are discussed. Of note, while GnRH has a key role in reproduction, AKH and CRZ show pleiotropic activities in the adult fly, primarily in metabolism and stress responses. From a protein evolution standpoint, the $\mathrm{GnRH} / \mathrm{AKH} / \mathrm{CRZ}$ family nicely demonstrates the developmental process of neuropeptide signaling systems emerging from a putative common ancestor and leading to divergent activities in distal phyla.
\end{abstract}

Keywords: gonadotropin-releasing hormone $(\mathrm{GnRH})$; adipokinetic hormone $(\mathrm{AKH})$; corazonin (CRZ); Drosophila melanogaster (Drosophila)

\section{Introduction}

The hypothalamic-pituitary-gonadal (HPG) axis is a key endocrine axis in the reproduction of vertebrates. The decapeptide gonadotropin-releasing hormone $(\mathrm{GnRH})$ is secreted in a pulsatile manner from the hypothalamus and controls the biosynthesis and secretion of the gonadotropins luteinizing hormone (LH) and follicle-stimulating hormone (FSH) from the pituitary gonadotropes [1-3]. LH and FSH regulate steroidogenesis and gametogenesis in the gonads, and feedback loops consisting of gonadal hormones are involved in the regulation of $\mathrm{GnRH}$ and gonadotropin biosynthesis to tune their levels for successful reproduction [4-6]. It is well established that the GnRH receptor is primarily expressed in the pituitary, though expression in additional organs has been identified, and potential effects of GnRH have been documented outside the pituitary in physiological and disease states (e.g., direct activity on the prostate, mammary gland and a possible role in the placenta and gonads; for example, see [7-11]). The GnRH receptor is a Gprotein coupled receptor, which consists of seven-transmembrane helices coupled to a G-protein and leading to the activation of an intracellular effector and generation of second messenger/s [1,2,12-15].

For many decades, the components of the HPG axis have virtually only been associated with vertebrates, though genome analyses and bioinformatics tools developed in the last 30 years enable us to identify evolutionarily and structurally related gene encoding hormones and receptors of the GnRH and the gonadotropins in several phyla of 
the animal kingdom (for review, see example [16-18]). It is generally accepted that the members of these two families, identified in different clades, probably share common roots in evolution [17-23]. However, their primary function has diverged in different phyla and vary, especially among invertebrate species. This review will focus on two GnRH related peptides—adipokinetic hormone (AKH) and corazonin (CRZ) [24-29]—in Drosophila melanogaster and emphasize their activities at the adult stage (imago). The AKH and CRZ signaling systems have been identified in invertebrates and were linked to the mammalian GnRH system based on putative similarities of the precursor gene organization and the processing of the preprohormones to the active peptides. However, the exact connection of the three ligand/receptor pairs is still not unambiguously resolved. Significant differences in the sequence and the activities of AKH and CRZ compared to GnRH (Figure 1 and see below) complicate the possibility to precisely determine the nature of the homology, and whether they are indeed "true" orthologs or paralogs, and this intriguing issue is beyond the scope of the current review. Of note, recent reviews address the evolutionary relationships with emphasis on the gene duplication rounds and loss events that led to the development of GnRH/AKH/CRZ systems and their repertoire in various metazoans [30,31]. Nevertheless, on the basis of (mainly) genomic analyses, these peptides and their receptors are generally considered as evolutionarily related and can be viewed and classified as members of the same superfamily (the GnRH family) rather than unrelated neurohormone and receptor pairs $[19,21,23,30-33]$.

Sequence comparison of the mature peptides:

$\begin{array}{lllllllllll}1 & 2 & 3 & 4 & 5 & 6 & 7 & 8 & 9 & 10\end{array}$

- Mammalian GnRH: pGlu -His -Trp -Ser -Tyr -Gly -Leu -Arg -Pro -Gly

- Drosophila AKH: pGlu -Leu -Thr -Phe -Ser -Pro -Asp -Trp

- Drosophila CRZ: pGlu -Thr -Phe -Gln -Tyr -Ser -Arg -Gly -Trp -Thr -Asn

Figure 1. Sequence comparison of the mature GnRH/AKH/CRZ peptides. GnRH consisted of 10 amino acid residues, whereas AKH and CRZ peptides consisted of 8 and 11 amino acid residues. The amino acid residues are marked in their standard 3 letters code, and pGlu denotes pyroglutamic acid (a cyclical amino acid found in many secreted peptides). The position of the amino acid residue in the neurohormone is superscript numbered. Please note that proline is present at position 9 of GnRH and position 6 of AKH but not in CRZ, predicating differences in the secondary structure and folding of the three peptides.

\section{AKH Expression, Secretion and Overall Function in Drosophila}

Like vertebrates, insects, including Drosophila, have numerous neuropeptide eliciting hormonal signals and complex signaling networks [34-37]. AKH is a peptidic neurohormone of 8-10 amino acid residues synthesized in the corpus cardiacum, which is part of the ring gland [24]. The ring gland is tissue connected to the brain and serves as a major endocrine organ during the larval-pupal-adult developmental phases and is viewed as the pituitary homolog in insects, including Drosophila [38-41].

In Drosophila, the AKH gene and peptide sequences have been reported some 30 years ago [42,43]. Drosophila AKH is an octapeptide, which was isolated from larvae and adults and was detected in higher levels in females [42], and although its size is about that of $\mathrm{GnRH}$, the amino acid composition is different (Figure 1). About a decade later, AKH was identified as the ligand for a previously identified homolog of the mammalian GnRH receptor $[44,45]$.

Unlike GnRH, the processes of the biosynthesis, the release and turnover of $\mathrm{AKH}$ in Drosophila, are largely unknown. For example, while a pulsatile secretion and half-life in the range of few minutes are hallmarks of GnRH $[3,46]$, for the best of my knowledge, these issues have not been reported for AKH and CRZ in these flies. A very recent study in adult Drosophila identified multiple ion channel genes expressed in the neuroendocrine cells that synthesize and release AKH into the hemolymph when energy levels are low [47]. 
The mechanism of AKH secretion includes gating the $\mathrm{K}^{+}$ATP channel and the subsequent opening of $\mathrm{Ca}^{++}$and $\mathrm{K}^{+}$ion channels, with a crucial role of the AMP-activated protein kinase (AMPK) [47]. The authors suggested the changes in AKH cell excitability couples nutrient sensing (e.g., low circulating sugar levels) to the exocytosis of the neurohormone to regulate metabolism, a key function of the neurohormone in adult flies $([48,49]$ and see below).

\section{The AKH Receptor}

A single AKH receptor was identified in Drosophila on the basis of various computational approaches. A putative receptor, which is structurally related to $\mathrm{GnRH}$ receptor, was cloned in Drosophila by Hauser, Sondergaard and Grimmelikhuijzan [44], and subsequently, Grimmelikhuijzan and Adams' teams, identified AKH as its ligand [23,45]. The "de-orphanization" of the Drosophila GnRH-like receptor enabled them to decipher the association between AKH in insects and GnRH in mammals [19-21]. The AKH receptor was identified in various organs and tissues in Drosophila, including the fat body (the prime AKH target), the CNS and the crop (the crop is a sack-like organ; part of the gut that serves as a major storage organ for carbohydrates (and possibly for lipids) consumed by adult flies). Similar to the mechanism of action of the mammalian GnRH receptor, the Drosophila AKHR couples in the fat body to the G $\alpha$ q/PLC pathway and $\mathrm{Ca}^{2+}$, an intracellular messenger of AKH [45,50]. I will summarize some major identified activities of the signaling systems of AKH and CRZ below.

\section{Activities of the AKH/AKHR Signaling System in Drosophila}

Initially, similar to the then already known cardio acceleration activity of AKH peptides in insect larvae, an increase in heart rate at the prepupa developmental stage was the first activity identified in Drosophila [42], and subsequently, diverse physiological activities have been identified up until the end of metamorphosis. Unlike in vertebrates, where the primary role of GnRH in adults is reproduction, in adult insects (imagoes), the most prominent role of AKH is related to metabolism. In adult Drosophila, AKH has a major role in carbohydrate and lipid metabolism, especially when high levels of energy are needed, such as in flying, locomotion and in stress conditions (e.g., starvation) [51]. The peptide induces triglyceride and glycogen break down in the fat body (the homolog of the liver and adipose tissue), increasing trehalose (a major sugar in insects) and free fatty acids and glycerol levels in the hemolymph [51]. Overall, although there is no evidence for a crosstalk at the molecular level, the energy mobilization activity of AKH is functionally antagonistic to that of the members of Drosophila insulin-like peptides. Hence, from a functional standpoint, based on its major function on metabolism and opposing the insulinlike system in adult flies, $\mathrm{AKH}$ is considered as a glucagon equivalent. In addition, the cardio stimulatory action of $\mathrm{AKH}$ in insects may be regarded as analogous to the direct cardiac effects of biogenic amines in mammals (e.g., adrenaline). Collectively, although evolutionarily and structurally related to $\mathrm{GnRH}$, from the functional standpoint, in insects, AKH has activities similar to glucagon and adrenaline in mammals. Of note, glucagon has opposite metabolic effects compared to insulin but also a positive chronotropic effect on the heart [52,53]. Accordingly, it is generally viewed that in Drosophila, AKH has a glucagon-like activity without necessitating to the catecholamine.

A high-sugar diet results in hyperglycemia, insulin resistance, metabolic-like syndrome and enhanced tumorigenesis in Drosophila [54-56]. Song et al. discovered an intriguing crosstalk between Activin $\beta$ and AKH in the adult fat body and showed that a high-sucrose diet (high-caloric) enhanced AKH action in the fat body, resulting in hyperglycemia [57]. Activin $\beta$ secretion from the midgut is increased with a high-sugar diet, and the hormone activates the activin type 1 receptor, and this, in turn, enhances $\mathrm{AKH}$ receptor expression and increases AKH signaling in the fat body to promote hyperglycemia [57]. These results were consistent with a previous study by Musselman et al. that showed an increase in $\mathrm{AKH}$ receptor expression and enhanced $\mathrm{AKH}$ sensitivity in the fat body in 
response to a high-sugar diet and demonstrated an insulin-independent mechanism for hyperglycemia related to the diet [58]. This further supports the functional homology of Drosophila AKH to glucagon in mammals.

The exchange of information between the brain and the gut is important for regulating feeding, and this communication involves numerous neurotransmitters and neurohormones. A recent study identified crucial mediators of brain-gut and gut-brain communication as related to feeding and found that $\mathrm{AKH}$, serotonin and octopamine modulate the crop muscle contractions in adult Drosophila [59]. Using electrophysiological recordings of crop muscle activity in response to exogenous stimulation of the organ with various substances, the authors reported that while serotonin increased both the amplitude and frequency of crop contraction rate, AKH mainly enhanced the frequency. In contrast, octopamine had an opposite effect, and the neurotransmitter silenced the crop motility [59]. In addition, while the accepted role of $\mathrm{AKH}$ is to mobilize carbohydrates from stored glycogen in the fat body, this study provided support to a previously raised possibility [51] that AKH also acts on the crop in order to increase the sugar levels in the hemolymph and provides usable energy when needed by means of pushing stored carbohydrates into the midgut for digestion [59].

Communication between tissues that involves $\mathrm{AKH}$ to control circulating lipid levels and energy homeostasis was also demonstrated between skeletal muscles and the intestine and fat body [60]. This study demonstrated a hormonal circuit involving the myokine Upd2 and AKH secreted from the corpora cardiacum that, depending on the muscle activity, can coordinate energy demands as related to lipid synthesis and storage. The authors suggested that this muscle-corpora cardiacum-fat-body/intestine communication enables the muscles to regulate fat turnover in response to the circadian feeding and activity changes as a mechanism to maintain the fly's lipid hemeostasis [60].

Recently, Scopelliti and colleagues demonstrated a complex intestinal/neuronal/adiposetissue communication network in the adult fly, in which AKH/AKHR signaling is a key switch, connecting nutrient sensing to the regulation of metabolic homeostasis [61]. This study suggested that in response to dietary sugars sensed and absorbed by the gut enterocytes (enteroendocrine cells), these cells secrete Bursicon $\alpha$ to circulation, leading to the activation of its receptor (dLGR2) in neurons that contact AKH neurons to regulate AKH production in the CNS [61]. The Bursicon $\alpha /$ dLGR2 activity results in a reduced AKH secretion from the corpora cardiacum, leading to a decrease in AKHR receptor activity in the adipose tissue in the fat body, low intracellular $\mathrm{Ca}^{++}$levels and energy storage [61] (similar to the activity of the mammalian $\mathrm{GnRH}$ receptor, $\mathrm{Ca}^{++}$is the major second messenger of the AKHR). Bursiocon $\alpha$ is part of the Bursicon heterodimer, a key tanning hormone in insects, and its cognate receptor (dLGR2, also known as rickets, a leucine-reach repeats GPCR) are evolutionarily and structurally related to the glycoprotein hormones and their cognate receptors in mammals $[16-18,22,62,63]$. Curiously, if one tries to project the organization of the neuronal-endocrine model proposed by Scopelliti and colleagues to the messengers along the HPG in mammals, while GnRH is upstream to the gonadotropins to control gonadal function, the AKH/AKHR system is downstream to Bursicon $\alpha /$ dLGR2 to regulate energy homeostasis in Drosophila. In addition, while GnRH activity positively regulates gonadotropin biosynthesis and secretion, Scopellity and colleagues [61] proposed that circulating Bursicon $\alpha$ negatively regulates $\mathrm{AKH}$ secretion. Thus, in addition to the differences in the main physiological function, further deviation in mammals and insects exists between GnRH/gonadotropin and Bursicon/dLGR2, despite the structural and evolutionary connections between the components of these systems.

Energy metabolism is essential for optimal reproduction, and activity of AKH in the ovaries was also reported in insects (e.g., in mosquitos [64,65]). However, oogenesis in AKH deficient Drosophila appeared uncompromised as judged by the similar egg laying ability of AKH and AKH receptor mutants compared to control flies, and so far, no direct AKH effects on fertility have been reported in the fruit fly [66-68]. Lebreton and colleagues further demonstrated the relationship of metabolism to reproduction and reported that, depending on the nutritional conditions, AKH signaling is involved in the sexual behavior 
of Drosophila [69]. In flies lacking the AKH receptor, mating behavior of males, but not of females, was reduced, especially when starved. In addition, in relation to the nutritional status, the production of certain pheromones was changed in female, but not male flies [69]. One cannot rule out the possibility of identifying a direct role of AKH on fecundity and fertility in Drosophila or an activity in the gonads through a secreted mediator in an analogy to the HPG axis in mammals, but thus far, these were not clearly identified. Of note, a prominent effect of the $\mathrm{AKH} / \mathrm{AKH}$-receptor on reproduction was reported in several insect species, probably by decreasing energy mobilization and vitellogenin production to support egg production (for example, in female locusts of the species Locusta migratoria) [70]. In consistence with this, injecting AKH into adult female crickets (Gryllus bimaculatus) reduced egg production (for example, in the cricket Gryllus bimaculatus) [71]. Furthermore, in the nematode $C$. elegans, silencing the gene encoding the neurohormone or its receptor resulted in a delay in egg-laying (this can be compared to puberty in mammals) which implies a conservation of a GnRH/AKH role for normal sexual maturation, at least in the nematode [72].

The fruit fly has been extensively used for classical developmental studies primarily because of the powerful available genetic tools in this model organism. In addition to the major metabolic effects of energy mobilization in high-energy demanding activities as discussed above, many physiological activities have been reported in adult Drosophila. For example, Jourjine and colleagues showed that in a small population of neurons, consisting of four neurons, AKH elicits signals of nutrient deprivation in hunger state by means of elevating intracellular $\mathrm{Ca}^{++}$levels [73]. This study showed that the activities of the AKH receptor together with the cation channel Nanchung (Nan, a member of the TRPV) that senses extracellular osmolality oppositely control the fly's consumption of sugar and water as a mechanism that regulates the drives to eat and drink [73].

The connection between the well-known hyperactivity of starved flies, as part of their foraging behavior, to AKH was examined in several studies. Flies devoid of AKH producing neurons or the AKH receptor did not display the locomotor hyperactivity in response to starvation, suggesting a role for the neurohormone in the hyperactive behavior associated with food deprivation [51]. Similarly, in starved adult Drosophila lacking AKH producing cells, trehalose levels were decreased, and female as well as male flies became hypoactive and survived longer compared to non-AKH-ablated flies under starvation [74]. Further evidence for the connection between $\mathrm{AKH}$ and locomotor activity was seen when knocking down AKH receptors in a small group of octopaminergic neurons (the biogenic amine octopamine is an invertebrate homolog of norepinephrine) in the fly brain, but not in the fat body, abolished the starvation-induced hyperactivity [75]. Both AKH and octopamine are crucial for the starvation-induced hyperactivity, and this study pointed to neuro-modulatory and behavioral roles of AKH in food searching when food is deficient. Subsequently, the same group showed that flies on a high-fat-diet (but not on a high-sucrose diet) became more sensitive to starvation that is manifested in an increase in the levels of the AKH receptor in these octopaminergic neurons in the fly brain and enhance their excitability [76]. This results in an hyperlocomotion behavior when starved compared to flies that were on a regular diet [76]. It was also found that a combined AKH action in the brain and fat body (in association with the octopaminergic system) fine-tunes day and night locomotion of flies with unrestricted access to food [77]. In addition, an enhanced AKH action resulted in a prolonged lifespan of water-sensing mutant female flies [78]. A recent study also reported a longer median lifespan of female AKH mutant Drosophila compared to control flies when fed on a high fat diet or normal diet [79]. All in all, only subtle physiological effects (including no clear effect of fecundity) and changes in the behavior and lipid status were observed during the aging of the AKH mutant [66]. Taken together, it is apparent that the despite the common evolutionary roots of $\mathrm{AKH}$ and $\mathrm{GnRH}$, the major functions of these neurohomones and the hierarchy with additional hormones differ in vertebrates and insects. 


\section{Corazonin Activities in the Fly}

Corazonin (or corazon; CRZ) is related to AKH and is an additional GnRH-like neuropeptide present in crustaceans and insects. In insects, this conserved neuropeptide is produced in neurosecretory cells and was first identified by Jan Veenstra as a heartbeat accelerator in the American cockroach, and subsequently, it was found that it has diverse physiological functions, generally related to various stress conditions. The Drosophila corazonin precursor gene was isolated from a genomic library and encoded a predicted signal peptide, the 11 amino acid corazonin sequence and an additional sequence of a putative peptide called corazonin-precursor-related peptide (CPRP) [25]. The structure of the corazonin precursor gene is very similar to the AKH gene, suggesting common evolutionary roots for the two neuropeptides $[25,30]$.

Ablation of CRZ expressing neurons in the adult brain of Drosophila increased survival under various stress conditions including starvation, oxidative and osmotic stresses compared to genetic background control flies [80]. In addition, and possibly in relation to the stress sensitivity, manipulations of CRZ neurons affected the locomotor activity of the flies, and interestingly, there were male and female dimorphic differences [80]. The levels of the corazonin transcript, triglyceride and dopamine were also affected in CRZ deficient flies under certain stress conditions and also showed sexual dimorphism [80]. Collectively, the authors [80] suggested that (a) stress reduces CRZ signaling, in consistence with previous microarrays studies [81]; (b) CRZ neuronal function differs in males and females (which was previously observed for dopamine [82]) and (c) response to stress involves both corazonin and dopamine signaling.

Kubark and his colleagues further showed the role of CRZ signaling in stress [83]. The authors found that CRZ receptors (CrzR) are expressed in the salivary gland and fat body of adult Drosophila [83]. Knocking-down CrzR expression in these organs resulted in an increased resistance to starvation and oxidative stress, an elevation in stored carbohydrate levels in starved (but not in fed) flies as well as a reduction in feeding and also had an influence on AKH and insulin-like peptide expression in the brain [83]. Based on these observations, it was suggested that peripheral CRZ affects carbohydrate metabolism, reduces resistance to various stress conditions (e.g., starvation, desiccation and oxidative stress), increases food intake and signals back to the brain to maintain metabolic homeostasis [83]. In the brain, it was shown that the fructose receptor Gr43a, which is important in nutrient sensing in the brain, is expressed in some of the CRZ neurons [84]. The authors suggested that CRZ is the likely neurotransmitter of Gr43a expressing neurons in the brain, providing the role of the neuropeptide in feeding [84]. A very recent study mapped the connectivity of CRZ and prothoracicotropic (PTTH) neurons and their projections to the prothoracic gland (PG) cells of male and female flies and also found that octopamine neurons function upstream to CRZ neurons [85]. This study showed that the CrzR activity negatively controls larval growth at a discrete advanced stage without affecting puparation by means of regulating ecdysteroid (ecdysone) production when PTTH levels are low [85]. The study deciphered an octopamine-CRZ-PTTH-ecdysone network that targets the PG and revealed a complex neuronal axis network, in which CRZ/CrzR is pivotal, that probably couples feeding to growth and maturation at the late larval stages prior to puparation [85].

It was also observed that CRZ neurons are involved in the behavioral response to ethanol in male flies. A reduced sensitivity to ethanol sedation was observed when the expression of the neuropeptide was reduced in a small population of neurons in the fly brain [86]. In CRZ neurons, the core autophagy gene, Atg16, has a role in the biosynthesis of the neuropeptide, regulating the ethanol intoxication behavior [87]. In addition, flies lacking CRZ neurons or the neuropeptide receptor had a delayed recovery following ethanol-induced sedation, and this extended hangover-like behavior was due to an altered alcohol metabolism [88]. Collectively, the CRZ/CrzR system apparently regulates both ethanol sensitivity and metabolism. A link between CRZ-expressing neurons and pleasurable fillings in Drosophila was further shown by Zer-Krispil and colleagues [89]. The authors exploited the previously identified role of CRZ in ejaculation and used several 
established reward parameters/assays to show that CRZ/CrzR signaling is a crucial part of the mating rewarding value in male flies. Interestingly, in the repeated activation of CRZ/CrzR signaling, the resulting ejaculation and rewarding aspects were associated with reduced ethanol consumption in the stimulated flies [89]. The authors suggested that the reduced motivation to consume the alcohol presumably resulted from the pleasurable effects of the CRZ signaling, implying a compensation between using ethanol and neurohormone signaling [89].

Reproduction-related activities of the CRZ system in Drosophila have been also reported. Tayler and colleagues showed that silencing of CRZ neurons resulted in male infertility [90]. The authors also found that CrzR expressing neurons innervate males' reproductive organs, and the CRZ/CrzR signaling system is a crucial component in the complex coordination of copulation duration and the transfer of sperm and seminal fluid [90]. In females, while overexpression of CRZ in the brain decreased vitellinogen (egg-yolk) and egg-laying rate, its knockdown led to opposite effects, suggesting that the neuropeptide has a negative effect on female Drosophila fertility [91]. In contrast, a positive correlation between CRZ expression and Drosophila fecundity was observed by Bergland and colleagues that suggested that female fecundity is affected by the concentrations of CRZ (positively correlated) and dopamine (negatively correlated) [92]. However, another study did not find prominent differences in the number of laid eggs along a 10 day period between CRZ receptor null mutant and wild-type control flies [88]. Together, the above studies do not provide a clear generic role of CRZ in Drosophila reproduction and demonstrate a possible sexual dimorphism in the role of the neuropeptide in male and female reproduction. In the silkworm Bombyx mori, it was shown that CRZ together with GABAnergic signaling regulate the formation of diapause eggs to unsure survival when conditions are changed to unfavorable [93]. Collectively, these and additional studies show that CRZ signaling is involved in many aspects of Drosophila physiology, mainly metabolism, when exposed to various stresses, but also as part of a reward mechanism associated with ethanol consumption and male reproductive activities.

\section{Summary Notes}

Despite the common roots of GnRH family members in different clades, the amino acid composition and the identified activities that evolved in various phyla diverged along the evolution. While GnRH is a key hormone regulating reproduction in mammals, in insects, AKH has mainly glucagon-like activities, and CRZ is involved in stress and metabolism, but also in fecundity feeding and rewarding activities (Figure 2). One common functional issue related to the GnRH-like peptides is that they appear to work in coordination with additional neurohormones/hormones and establish elaborated signaling networks that harmonize the activity of different organs.

\section{Common ancestor \\ GnRH in vertebrates (e.g., mammals) \\ AKH/CRZ in invertebrates (insects) (e.g., Drosophila)}

Secretion: Pulsatile Not yet reported

Half-life: Short Not yet reported

Major function/s: controlling reproduction Regulating metabolism and cardiac output especially under various stress conditions, and when high energy levels are required. Possible pleasure rewarding activity and a role in feeding

Figure 2. A comparison of some major aspects of GnRH/AKH/CRZ biology in mammals and insects. 
Funding: This research received no external funding.

Institutional Review Board Statement: Not applicable.

Informed Consent Statement: Not applicable.

Data Availability Statement: Not applicable.

Acknowledgments: I appreciate Fortune Kohen from the Weizmann institute for Science, Rehovot, Israel and Noah Isakov from Ben-Gurion University of the Negev, Israel for their comments and suggestions on the manuscript. The comments and suggestions of the anonymous reviewers are highly appreciated.

Conflicts of Interest: The author declares no conflict of interest.

\section{References}

1. Millar, R.P. GnRHs and GnRH receptors. Anim. Reprod. Sci. 2005, 88, 5-28. [CrossRef] [PubMed]

2. Naor, Z. Signaling by G-protein-coupled receptor (GPCR): Studies on the GnRH receptor. Front. Neuroendocrinol. 2009, 30, 10-29. [CrossRef] [PubMed]

3. Knobil, E. The hypothalamic gonadotrophic hormone releasing hormone (GnRH) pulse generator in the rhesus monkey and its neuroendocrine control. Hum. Reprod. 1988, 3, 29-31. [CrossRef] [PubMed]

4. Knobil, E. The neuroendocrine control of ovulation. Hum. Reprod. 1988, 3, 469-472. [CrossRef]

5. Casarini, L.; Crepieux, P.; Reiter, E.; Lazzaretti, C.; Paradiso, E.; Rochira, V.; Brigante, G.; Santi, D.; Simoni, M. FSH for the Treatment of Male Infertility. Int. J. Mol. Sci. 2020, 21, 2270. [CrossRef] [PubMed]

6. Holesh, J.E.; Bass, A.N.; Lord, M. Physiology, Ovulation; StatPearls: Treasure Island, FL, USA, 2021.

7. Ramakrishnappa, N.; Rajamahendran, R.; Lin, Y.M.; Leung, P.C. GnRH in non-hypothalamic reproductive tissues. Anim. Reprod. Sci. 2005, 88, 95-113. [CrossRef] [PubMed]

8. Fallah, H.P.; Habibi, H.R. Role of GnRH and GnIH in paracrine/autocrine control of final oocyte maturation. Gen. Comp. Endocrinol. 2020, 299, 113619. [CrossRef]

9. Fontana, F.; Marzagalli, M.; Montagnani Marelli, M.; Raimondi, M.; Moretti, R.M.; Limonta, P. Gonadotropin-Releasing Hormone Receptors in Prostate Cancer: Molecular Aspects and Biological Functions. Int. J. Mol. Sci. 2020, 21, 9511. [CrossRef]

10. Kraus, S.; Benard, O.; Naor, Z.; Seger, R. C-Src is Activated by the EGF Receptor in a Pathway that Mediates JNK and ERK Activation by Gonadotropin-Releasing Hormone in COS7 Cells. Int. J. Mol. Sci. 2020, 21, 8575. [CrossRef]

11. Fallah, H.P.; Rodrigues, M.S.; Corchuelo, S.; Nobrega, R.H.; Habibi, H.R. Role of GnRH Isoforms in Paracrine/Autocrine Control of Zebrafish (Danio rerio) Spermatogenesis. Endocrinology 2020, 161, bqaa004. [CrossRef]

12. Millar, R.P. New Insights into GnRH Neuron Development, Programming and Regulation in Health and Disease. Preface. Neuroendocrinology 2015, 102, 181-183. [CrossRef]

13. Naor, Z.; Huhtaniemi, I. Interactions of the GnRH receptor with heterotrimeric G proteins. Front. Neuroendocrinol. 2013, 34, 88-94. [CrossRef] [PubMed]

14. Krsmanovic, L.Z.; Stojilkovic, S.S.; Mertz, L.M.; Tomic, M.; Catt, K.J. Expression of gonadotropin-releasing hormone receptors and autocrine regulation of neuropeptide release in immortalized hypothalamic neurons. Proc. Natl. Acad. Sci. USA 1993, 90, 3908-3912. [CrossRef] [PubMed]

15. Tzoupis, H.; Nteli, A.; Androutsou, M.E.; Tselios, T. Gonadotropin-Releasing Hormone and GnRH Receptor: Structure, Function and Drug Development. Curr. Med. Chem. 2020, 27, 6136-6158. [CrossRef] [PubMed]

16. Van Loy, T.; Vandersmissen, H.P.; Van Hiel, M.B.; Poels, J.; Verlinden, H.; Badisco, L.; Vassart, G.; Vanden Broeck, J. Comparative genomics of leucine-rich repeats containing $\mathrm{G}$ protein-coupled receptors and their ligands. Gen. Comp. Endocrinol. 2008, 155, 14-21. [CrossRef] [PubMed]

17. Hauser, F.; Williamson, M.; Cazzamali, G.; Grimmelikhuijzen, C.J. Identifying neuropeptide and protein hormone receptors in Drosophila melanogaster by exploiting genomic data. Brief Funct. Genom. Proteomic 2006, 4, 321-330. [CrossRef]

18. Luo, C.W.; Hsueh, A.J. Genomic analyses of the evolution of LGR genes. Chang. Gung. Med. J. 2006, 29, 2-8. [PubMed]

19. Hauser, F.; Grimmelikhuijzen, C.J. Evolution of the AKH/corazonin/ACP/GnRH receptor superfamily and their ligands in the Protostomia. Gen. Comp. Endocrinol. 2014, 209, 35-49. [CrossRef]

20. Lindemans, M.; Janssen, T.; Beets, I.; Temmerman, L.; Meelkop, E.; Schoofs, L. Gonadotropin-releasing hormone and adipokinetic hormone signaling systems share a common evolutionary origin. Front. Endocrinol. 2011, 2, 16. [CrossRef]

21. Zandawala, M.; Tian, S.; Elphick, M.R. The evolution and nomenclature of GnRH-type and corazonin-type neuropeptide signaling systems. Gen. Comp. Endocrinol. 2018, 264, 64-77. [CrossRef]

22. Van Loy, T.; Van Hiel, M.B.; Vandersmissen, H.P.; Poels, J.; Mendive, F.; Vassart, G.; Vanden Broeck, J. Evolutionary conservation of bursicon in the animal kingdom. Gen. Comp. Endocrinol. 2007, 153, 59-63. [CrossRef]

23. Park, Y.; Kim, Y.J.; Adams, M.E. Identification of G protein-coupled receptors for Drosophila PRXamide peptides, CCAP, corazonin, and AKH supports a theory of ligand-receptor coevolution. Proc. Natl. Acad. Sci. USA 2002, 99, 11423-11428. [CrossRef] [PubMed] 
24. O'Shea, M.; Rayne, R.C. Adipokinetic hormones: Cell and molecular biology. Experientia 1992, 48, 430-438. [CrossRef]

25. Veenstra, J.A. Isolation and structure of the Drosophila corazonin gene. Biochem. Biophys. Res. Commun. 1994, $204,292-296$. [CrossRef] [PubMed]

26. Veenstra, J.A. Isolation and structure of corazonin, a cardioactive peptide from the American cockroach. FEBS Lett. 1989, 250, 231-234. [CrossRef]

27. Oh, Y.; Lai, J.S.; Mills, H.J.; Erdjument-Bromage, H.; Giammarinaro, B.; Saadipour, K.; Wang, J.G.; Abu, F.; Neubert, T.A.; Suh, G.S.B. A glucose-sensing neuron pair regulates insulin and glucagon in Drosophila. Nature 2019, 574, 559-564. [CrossRef] [PubMed]

28. Andreatta, G.; Broyart, C.; Borghgraef, C.; Vadiwala, K.; Kozin, V.; Polo, A.; Bileck, A.; Beets, I.; Schoofs, L.; Gerner, C.; et al. Corazonin signaling integrates energy homeostasis and lunar phase to regulate aspects of growth and sexual maturation in Platynereis. Proc. Natl. Acad. Sci. USA 2020, 117, 1097-1106. [CrossRef]

29. Tran, N.M.; Mykles, D.L.; Elizur, A.; Ventura, T. Characterization of G-protein coupled receptors from the blackback land crab Gecarcinus lateralis Y organ transcriptome over the molt cycle. BMC Genom. 2019, 20, 74. [CrossRef]

30. Dufour, S.; Querat, B.; Tostivint, H.; Pasqualini, C.; Vaudry, H.; Rousseau, K. Origin and Evolution of the Neuroendocrine Control of Reproduction in Vertebrates, With Special Focus on Genome and Gene Duplications. Physiol. Rev. 2020, 100, 869-943. [CrossRef] [PubMed]

31. Sakai, T.; Shiraishi, A.; Kawada, T.; Matsubara, S.; Aoyama, M.; Satake, H. Invertebrate Gonadotropin-Releasing Hormone-Related Peptides and Their Receptors: An Update. Front. Endocrinol. 2017, 8, 217. [CrossRef]

32. Grimmelikhuijzen, C.J.; Hauser, F. Mini-review: The evolution of neuropeptide signaling. Regul. Pept. 2012, 177, S6-S9. [CrossRef] [PubMed]

33. Gade, G.; Simek, P.; Marco, H.G. The Adipokinetic Peptides in Diptera: Structure, Function, and Evolutionary Trends. Front. Endocrinol. 2020, 11, 153. [CrossRef] [PubMed]

34. Nassel, D.R.; Zandawala, M. Recent advances in neuropeptide signaling in Drosophila, from genes to physiology and behavior. Prog. Neurobiol. 2019, 179, 101607. [CrossRef] [PubMed]

35. Taghert, P.H.; Veenstra, J.A. Drosophila neuropeptide signaling. Adv. Genet. 2003, 49, 1-65. [PubMed]

36. Deng, B.; Li, Q.; Liu, X.; Cao, Y.; Li, B.; Qian, Y.; Xu, R.; Mao, R.; Zhou, E.; Zhang, W.; et al. Chemoconnectomics: Mapping Chemical Transmission in Drosophila. Neuron 2019, 101, 876-893 e4. [CrossRef]

37. Ormerod, K.G.; Jung, J.; Mercier, A.J. Modulation of neuromuscular synapses and contraction in Drosophila 3rd instar larvae. J. Neurogenet. 2018, 32, 183-194. [CrossRef] [PubMed]

38. Dai, J.D.; Gilbert, L.I. Metamorphosis of the corpus allatum and degeneration of the prothoracic glands during the larval-pupaladult transformation of Drosophila melanogaster: A cytophysiological analysis of the ring gland. Dev. Biol. 1991, 144, 309-326. [CrossRef]

39. Dai, J.D.; Henrich, V.C.; Gilbert, L.I. An ultrastructural analysis of the ecdysoneless (1(3)ecd1ts) ring gland during the third larval instar of Drosophila melanogaster. Cell Tissue Res. 1991, 265, 435-445. [CrossRef] [PubMed]

40. De Velasco, B.; Shen, J.; Go, S.; Hartenstein, V. Embryonic development of the Drosophila corpus cardiacum, a neuroendocrine gland with similarity to the vertebrate pituitary, is controlled by sine oculis and glass. Dev. Biol. 2004, 274, 280-294. [CrossRef]

41. Pesch, Y.Y.; Hesse, R.; Ali, T.; Behr, M. A cell surface protein controls endocrine ring gland morphogenesis and steroid production. Dev. Biol. 2019, 445, 16-28. [CrossRef]

42. Noyes, B.E.; Katz, F.N.; Schaffer, M.H. Identification and expression of the Drosophila adipokinetic hormone gene. Mol. Cell Endocrinol. 1995, 109, 133-141. [CrossRef]

43. Schaffer, M.H.; Noyes, B.E.; Slaughter, C.A.; Thorne, G.C.; Gaskell, S.J. The fruitfly Drosophila melanogaster contains a novel charged adipokinetic-hormone-family peptide. Biochem. J. 1990, 269, 315-320. [CrossRef]

44. Hauser, F.; Sondergaard, L.; Grimmelikhuijzen, C.J. Molecular cloning, genomic organization and developmental regulation of a novel receptor from Drosophila melanogaster structurally related to gonadotropin-releasing hormone receptors for vertebrates. Biochem. Biophys. Res. Commun. 1998, 249, 822-828. [CrossRef] [PubMed]

45. Staubli, F.; Jorgensen, T.J.; Cazzamali, G.; Williamson, M.; Lenz, C.; Sondergaard, L.; Roepstorff, P.; Grimmelikhuijzen, C.J. Molecular identification of the insect adipokinetic hormone receptors. Proc. Natl. Acad. Sci. USA 2002, 99, 3446-3451. [CrossRef] [PubMed]

46. Leibovitz, D.; Koch, Y.; Pitzer, F.; Fridkin, M.; Dantes, A.; Baumeister, W.; Amsterdam, A. Sequential degradation of the neuropeptide gonadotropin-releasing hormone by the $20 \mathrm{~S}$ granulosa cell proteasomes. FEBS Lett. 1994, 346, 203-206. [PubMed]

47. Perry, R.J.; Saunders, C.J.; Nelson, J.M.; Rizzo, M.J.; Braco, J.T.; Johnson, E.C. Regulation of Metabolism by an Ensemble of Different Ion Channel Types: Excitation-Secretion Coupling Mechanisms of Adipokinetic Hormone Producing Cells in Drosophila. Front. Physiol. 2020, 11, 580618. [CrossRef]

48. Van der Horst, D.J. Insect adipokinetic hormones: Release and integration of flight energy metabolism. Comp. Biochem. Physiol. B Biochem. Mol. Biol. 2003, 136, 217-226. [CrossRef]

49. Vroemen, S.F.; Van der Horst, D.J.; Van Marrewijk, W.J. New insights into adipokinetic hormone signaling. Mol. Cell Endocrinol. 1998, 141, 7-12. [CrossRef]

50. Baumbach, J.; Xu, Y.; Hehlert, P.; Kuhnlein, R.P. Galphaq, Ggamma1 and Plc21C control Drosophila body fat storage. J. Genet. Genom. 2014, 41, 283-292. [CrossRef] 
51. Lee, G.; Park, J.H. Hemolymph sugar homeostasis and starvation-induced hyperactivity affected by genetic manipulations of the adipokinetic hormone-encoding gene in Drosophila melanogaster. Genetics 2004, 167, 311-323. [CrossRef]

52. Hernandez-Cascales, J. Does glucagon have a positive inotropic effect in the human heart? Cardiovasc. Diabetol. 2018, 17, 148. [CrossRef] [PubMed]

53. Lucchesi, B.R. Cardiac actions of glucagon. Circ. Res. 1968, 22, 777-787. [CrossRef] [PubMed]

54. Hirabayashi, S.; Baranski, T.J.; Cagan, R.L. Transformed Drosophila cells evade diet-mediated insulin resistance through wingless signaling. Cell 2013, 154, 664-675. [CrossRef] [PubMed]

55. Musselman, L.P.; Fink, J.L.; Narzinski, K.; Ramachandran, P.V.; Hathiramani, S.S.; Cagan, R.L.; Baranski, T.J. A high-sugar diet produces obesity and insulin resistance in wild-type Drosophila. Dis. Model. Mech. 2011, 4, 842-849. [CrossRef] [PubMed]

56. Pasco, M.Y.; Leopold, P. High sugar-induced insulin resistance in Drosophila relies on the lipocalin Neural Lazarillo. PLoS ONE 2012, 7, e36583. [CrossRef] [PubMed]

57. Song, W.; Cheng, D.; Hong, S.; Sappe, B.; Hu, Y.; Wei, N.; Zhu, C.; O'Connor, M.B.; Pissios, P.; Perrimon, N. Midgut-Derived Activin Regulates Glucagon-like Action in the Fat Body and Glycemic Control. Cell Metab. 2017, 25, 386-399. [CrossRef] [PubMed]

58. Musselman, L.P.; Fink, J.L.; Ramachandran, P.V.; Patterson, B.W.; Okunade, A.L.; Maier, E.; Brent, M.R.; Turk, J.; Baranski, T.J. Role of fat body lipogenesis in protection against the effects of caloric overload in Drosophila. J. Biol. Chem. 2013, 288, 8028-8042. [CrossRef]

59. Solari, P.; Rivelli, N.; De Rose, F.; Picciau, L.; Murru, L.; Stoffolano, J.G., Jr.; Liscia, A. Opposite effects of 5-HT/AKH and octopamine on the crop contractions in adult Drosophila melanogaster: Evidence of a double brain-gut serotonergic circuitry. PLoS ONE 2017, 12, e0174172. [CrossRef]

60. Zhao, X.; Karpac, J. Muscle Directs Diurnal Energy Homeostasis through a Myokine-Dependent Hormone Module in Drosophila. Curr. Biol. 2017, 27, 1941-1955 e6. [CrossRef]

61. Scopelliti, A.; Bauer, C.; Yu, Y.; Zhang, T.; Kruspig, B.; Murphy, D.J.; Vidal, M.; Maddocks, O.D.K.; Cordero, J.B. A Neuronal Relay Mediates a Nutrient Responsive Gut/Fat Body Axis Regulating Energy Homeostasis in Adult Drosophila. Cell Metab. 2019, 29, 269-284.e10. [CrossRef]

62. Hauser, F.; Nothacker, H.P.; Grimmelikhuijzen, C.J. Molecular cloning, genomic organization, and developmental regulation of a novel receptor from Drosophila melanogaster structurally related to members of the thyroid-stimulating hormone, folliclestimulating hormone, luteinizing hormone/choriogonadotropin receptor family from mammals. J. Biol. Chem. 1997, 272, 1002-1010.

63. Sellami, A.; Agricola, H.J.; Veenstra, J.A. Neuroendocrine cells in Drosophila melanogaster producing GPA2/GPB5, a hormone with homology to LH, FSH and TSH. Gen. Comp. Endocrinol. 2011, 170, 582-588. [CrossRef] [PubMed]

64. Kaufmann, C.; Merzendorfer, H.; Gade, G. The adipokinetic hormone system in Culicinae (Diptera: Culicidae): Molecular identification and characterization of two adipokinetic hormone (AKH) precursors from Aedes aegypti and Culex pipiens and two putative AKH receptor variants from A. aegypti. Insect Biochem. Mol. Biol. 2009, 39, 770-781. [CrossRef] [PubMed]

65. Oryan, A.; Wahedi, A.; Paluzzi, J.V. Functional characterization and quantitative expression analysis of two GnRH-related peptide receptors in the mosquito, Aedes aegypti. Biochem. Biophys. Res. Commun. 2018, 497, 550-557. [CrossRef] [PubMed]

66. Bednarova, A.; Tomcala, A.; Mochanova, M.; Kodrik, D.; Krishnan, N. Disruption of Adipokinetic Hormone Mediated Energy Homeostasis Has Subtle Effects on Physiology, Behavior and Lipid Status During Aging in Drosophila. Front. Physiol. 2018, 9, 949. [CrossRef]

67. Galikova, M.; Diesner, M.; Klepsatel, P.; Hehlert, P.; Xu, Y.; Bickmeyer, I.; Predel, R.; Kuhnlein, R.P. Energy Homeostasis Control in Drosophila Adipokinetic Hormone Mutants. Genetics 2015, 201, 665-683. [CrossRef] [PubMed]

68. Gronke, S.; Muller, G.; Hirsch, J.; Fellert, S.; Andreou, A.; Haase, T.; Jackle, H.; Kuhnlein, R.P. Dual lipolytic control of body fat storage and mobilization in Drosophila. PLoS Biol. 2007, 5, e137. [CrossRef] [PubMed]

69. Lebreton, S.; Mansourian, S.; Bigarreau, J.; Dekker, T. The Adipokinetic Hormone Receptor Modulates Sexual Behavior, Pheromone Perception and Pheromone Production in a Sex-Specific and Starvation-Dependent Manner in Drosophila melanogaster. Front. Ecol. Evol. 2016, 3, 151. [CrossRef]

70. Moshitzky, P.; Applebaum, S.W. The Role of Adipokinetic Hormone in the Control of Vitellogenesis in Locusts. Insect Biochem. 1990, 20, 319-323. [CrossRef]

71. Lorenz, M.W. Adipokinetic hormone inhibits the formation of energy stores and egg production in the cricket Gryllus bimaculatus. Comp. Biochem. Physiol. B Biochem. Mol. Biol. 2003, 136, 197-206. [CrossRef]

72. Lindemans, M.; Liu, F.; Janssen, T.; Husson, S.J.; Mertens, I.; Gade, G.; Schoofs, L. Adipokinetic hormone signaling through the gonadotropin-releasing hormone receptor modulates egg-laying in Caenorhabditis elegans. Proc. Natl. Acad. Sci. USA 2009, 106, 1642-1647. [CrossRef]

73. Jourjine, N.; Mullaney, B.C.; Mann, K.; Scott, K. Coupled Sensing of Hunger and Thirst Signals Balances Sugar and Water Consumption. Cell 2016, 166, 855-866. [CrossRef] [PubMed]

74. Isabel, G.; Martin, J.R.; Chidami, S.; Veenstra, J.A.; Rosay, P. AKH-producing neuroendocrine cell ablation decreases trehalose and induces behavioral changes in Drosophila. Am. J. Physiol Regul. Integr. Comp. Physiol. 2005, 288, R531-R538. [CrossRef]

75. Yu, Y.; Huang, R.; Ye, J.; Zhang, V.; Wu, C.; Cheng, G.; Jia, J.; Wang, L. Regulation of starvation-induced hyperactivity by insulin and glucagon signaling in adult Drosophila. Elife 2016, 5, e15693. [CrossRef] [PubMed] 
76. Huang, R.; Song, T.; Su, H.; Lai, Z.; Qin, W.; Tian, Y.; Dong, X.; Wang, L. High-fat diet enhances starvation-induced hyperactivity via sensitizing hunger-sensing neurons in Drosophila. Elife 2020, 9, e53103. [CrossRef]

77. Pauls, D.; Selcho, M.; Räderscheidt, J.; Amatobi, K.; Krischke, M.; Hermann-Luibl, C.; Helfrich-Förster, C.; Kühnlein, R.; Müller, M.; Wegener, C. Endocrine fine-tuning of daily locomotor activity patterns under non-starving conditions in Drosophila. bioRxiv 2020. [CrossRef]

78. Waterson, M.J.; Chung, B.Y.; Harvanek, Z.M.; Ostojic, I.; Alcedo, J.; Pletcher, S.D. Water sensor ppk28 modulates Drosophila lifespan and physiology through AKH signaling. Proc. Natl. Acad. Sci. USA 2014, 111, 8137-8142. [CrossRef] [PubMed]

79. Liao, S.; Amcoff, M.; Nassel, D.R. Impact of high-fat diet on lifespan, metabolism, fecundity and behavioral senescence in Drosophila. Insect Biochem. Mol. Biol. 2020, 103495. [CrossRef] [PubMed]

80. Zhao, Y.; Bretz, C.A.; Hawksworth, S.A.; Hirsh, J.; Johnson, E.C. Corazonin neurons function in sexually dimorphic circuitry that shape behavioral responses to stress in Drosophila. PLoS ONE 2010, 5, e9141. [CrossRef] [PubMed]

81. Harbison, S.T.; Chang, S.; Kamdar, K.P.; Mackay, T.F. Quantitative genomics of starvation stress resistance in Drosophila. Genome Biol. 2005, 6, R36. [CrossRef] [PubMed]

82. Yellman, C.; Tao, H.; He, B.; Hirsh, J. Conserved and sexually dimorphic behavioral responses to biogenic amines in decapitated Drosophila. Proc. Natl. Acad. Sci. USA 1997, 94, 4131-4136. [CrossRef] [PubMed]

83. Kubrak, O.I.; Lushchak, O.V.; Zandawala, M.; Nassel, D.R. Systemic corazonin signalling modulates stress responses and metabolism in Drosophila. Open Biol. 2016, 6, 160152. [CrossRef] [PubMed]

84. Miyamoto, T.; Amrein, H. Diverse roles for the Drosophila fructose sensor Gr43a. Fly 2014, 8, 19-25. [CrossRef]

85. Imura, E.; Shimada-Niwa, Y.; Nishimura, T.; Huckesfeld, S.; Schlegel, P.; Ohhara, Y.; Kondo, S.; Tanimoto, H.; Cardona, A.; Pankratz, M.J.; et al. The Corazonin-PTTH Neuronal Axis Controls Systemic Body Growth by Regulating Basal Ecdysteroid Biosynthesis in Drosophila melanogaster. Curr. Biol. 2020, 30, 2156-2165.e5. [CrossRef]

86. McClure, K.D.; Heberlein, U. A small group of neurosecretory cells expressing the transcriptional regulator apontic and the neuropeptide corazonin mediate ethanol sedation in Drosophila. J. Neurosci. 2013, 33, 4044-4054. [CrossRef] [PubMed]

87. Varga, K.; Nagy, P.; Arsikin Csordas, K.; Kovacs, A.L.; Hegedus, K.; Juhasz, G. Loss of Atg16 delays the alcohol-induced sedation response via regulation of Corazonin neuropeptide production in Drosophila. Sci. Rep. 2016, 6, 34641. [CrossRef] [PubMed]

88. Sha, K.; Choi, S.H.; Im, J.; Lee, G.G.; Loeffler, F.; Park, J.H. Regulation of ethanol-related behavior and ethanol metabolism by the Corazonin neurons and Corazonin receptor in Drosophila melanogaster. PLoS ONE 2014, 9, e87062. [CrossRef] [PubMed]

89. Zer-Krispil, S.; Zak, H.; Shao, L.; Ben-Shaanan, S.; Tordjman, L.; Bentzur, A.; Shmueli, A.; Shohat-Ophir, G. Ejaculation Induced by the Activation of Crz Neurons Is Rewarding to Drosophila Males. Curr. Biol. 2018, 28, 1445-1452.e3. [CrossRef] [PubMed]

90. Tayler, T.D.; Pacheco, D.A.; Hergarden, A.C.; Murthy, M.; Anderson, D.J. A neuropeptide circuit that coordinates sperm transfer and copulation duration in Drosophila. Proc. Natl. Acad. Sci. USA 2012, 109, 20697-20702. [CrossRef]

91. Gospocic, J.; Shields, E.J.; Glastad, K.M.; Lin, Y.; Penick, C.A.; Yan, H.; Mikheyev, A.S.; Linksvayer, T.A.; Garcia, B.A.; Berger, S.L.; et al. The Neuropeptide Corazonin Controls Social Behavior and Caste Identity in Ants. Cell 2017, 170, 748-759.e12. [CrossRef] [PubMed]

92. Bergland, A.O.; Chae, H.S.; Kim, Y.J.; Tatar, M. Fine-scale mapping of natural variation in fly fecundity identifies neuronal domain of expression and function of an aquaporin. PLoS Genet. 2012, 8, e1002631. [CrossRef] [PubMed]

93. Tsuchiya, R.; Kaneshima, A.; Kobayashi, M.; Yamazaki, M.; Takasu, Y.; Sezutsu, H.; Tanaka, Y.; Mizoguchi, A.; Shiomi, K. Maternal GABAergic and GnRH/corazonin pathway modulates egg diapause phenotype of the silkworm Bombyx mori. Proc. Natl. Acad. Sci. USA 2021, 118, e2020028118. [CrossRef] [PubMed] 